\title{
Application of green fluorescent protein to measure antimicrobial efficacy and the kinetics of cell death against Escherichia coli
}

DOI:

10.1016/j.mimet.2017.08.005

\section{Document Version}

Accepted author manuscript

Link to publication record in Manchester Research Explorer

Citation for published version (APA):

Greenhalgh, R., Greenhalgh, M., Alshareef, F., \& Robson, G. D. (2017). Application of green fluorescent protein to measure antimicrobial efficacy and the kinetics of cell death against Escherichia coli. Journal of Microbiological Methods, 141, 67-72. https://doi.org/10.1016/j.mimet.2017.08.005

Published in:

Journal of Microbiological Methods

\section{Citing this paper}

Please note that where the full-text provided on Manchester Research Explorer is the Author Accepted Manuscript or Proof version this may differ from the final Published version. If citing, it is advised that you check and use the publisher's definitive version.

\section{General rights}

Copyright and moral rights for the publications made accessible in the Research Explorer are retained by the authors and/or other copyright owners and it is a condition of accessing publications that users recognise and abide by the legal requirements associated with these rights.

\section{Takedown policy}

If you believe that this document breaches copyright please refer to the University of Manchester's Takedown Procedures [http://man.ac.uk/04Y6Bo] or contact uml.scholarlycommunications@manchester.ac.uk providing relevant details, so we can investigate your claim.

\section{OPEN ACCESS}




\section{REVISION}

\section{Application of Green Fluorescent Protein to measure antimicrobial efficacy and the kinetics of cell death against Escherichia coli}

6

7 Richard Greenhalgh ${ }^{1}$, Malcolm Greenhalgh ${ }^{2}$ Fadwa Alshareef $^{3}$ and

8 Geoffrey. D. Robson ${ }^{1 *}$

9 1. School of Biological Sciences, Faculty of Biology, Medicine and Health, Michael 10 Smith Building, University of Manchester, Manchester, UK

11 2. MG Consultants Ltd, Byers Green, Spennymoor, UK

${ }^{*}$ Corresponding author

Tel: $+44(0) 1612755048$

Email: Geoff.robson@manchester.ac.uk

Running title: eGFP as a real-time viability marker 


\title{
Highlights
}

- Fluorescent intensity of cytosolic eGFP is strongly correlated with viability.

- Assay enables the kinetics of cell death in response to antimicrobials to be monitored in real time.

- Differentiates between biocidal and biostatic effects.

- Demonstrated differences in antimicrobial efficacy against growing and nongrowing cells.

\begin{abstract}
Industrial antimicrobials have been extensively used to control unwanted microbial growth by incorporation into a variety of products such as plastics and paints, reducing biodeterioration and biofouling and extending the lifespan of the product. Industrial antimicrobials generally have broad sites of action affecting core cellular functions such as central metabolism, enzyme function, cell wall or DNA synthesis and can either be biocidal or biostatic. In addition, susceptibility can be affected by the metabolic state of the microbe, with metabolically inactive cells generally more resistant than metabolically active cells. Previously it was demonstrated that cytosolically expressed green fluorescent protein could be used as a real-time viability indicator in the yeast Aureobasdium pullulans based on the $\mathrm{pH}$ dependent fluorescence of GFP and the collapse of the proton gradient across the cell membrane during cell death. In this study we report on the development and validation of an equivalent GFP fluorescence viability assay in Escherichia coli and used this assay to study the effect of five antimicrobialss commonly used in plastics; 4,5-dichloro-2-octyl-isothiazol-3-one (DCOIT), sodium pyrithione, 1,2-benzisothiazol3-one (BIT), 2-0ctyl-isothiazol-3-one (OIT) and n-butyl-1,2-benzisothiazol-3-one (BBIT). The results demonstrate broad diiferences amongst the antimicrobials in both relative efficacy, rate of effect and for some antimicrobials, marked differences in sensitivy toward growing and non-growing cells.
\end{abstract}

\section{Key words}

Antimicrobial efficacy, eGFP, Escherichia coli, viability assay 


\section{Introduction}

Industrial antimicrobials refer to inorganic and organic compounds with antimicrobial activity that are extensively used commercially by incorpration into a range of commodities including plastics, paints, textiles, wood composites, cosmetics and pharmaceuticals as well as in swimming pools and metal working fluids where they act as protectants against microbes (Rossmoore, 1995; Karsa and Ashworth, 2002; Chapman, 2003; Swedish Chemical Agency, 2012a). In the plastics industy, consumption of antimicrobials was estimated to be ca. 15.4 million tonnes in 2005 with a value of ca. $£ 34$ million (Markarian, 2006). While accurate figures are difficult to ascertain, it has been estimated that the true cost of biodeterioration of non-food items globally due to microbial activities could reach $\$ 40$ billion annually (Allsopp, 2011).

Industrial antimicrobials can be largely classified depending on their site of action such as the cell wall, membrane or cytoplasm and often have broad physiological and biochemical effects which are still largely uncharacterised in detail (Denyer, 1995; Paulus, 2005; Lambert 2008). Many target essential cellular processes leading to a cessation of growth and/or cell death. For example, the widely used isothiazolone agents have been shown to target the thiol group of proteins including hydroxylases leading to metabolic impairment, whereas cationic agents such as chlorhexidine are thought to act primarily at the cell surface (Denyer, 1995; Maillard, 2002; Paulus, 2005).

Testing the efficacy of single or combinations of antimicrobials has largely relied on direct or indirect measurements of growth retardation against specific test 
organisms using disc diffusion or broth dilution assays and many ISO standards for determining antimicrobial efficacy are still based on these methodologies (Bloomfield, 1991; Swedish Chemical Agency, 2012b; Kun and Marossy, 2013). Attempts have been made to introduce alternative methods for evaluating cell viability and antimicrobial efficacy in recent years (Davey, 2011). For example, bioluminescence in engineered bacterial strains including E.coli have been shown to be useful in situ markers of cell viability as light generation is a metabolically active process relying on ATP procuvtion by viable cells (Jones et al., 2002; Alloush et al., 2003; Robinson et al., 2011; Thorn et al., 2013). Other methods studied have included the reduction of tetrazolium salts, live/dead cell staining and measuring ATP content (Petty et al., 1995; Boulos et al., 1999; Zhang and Fang, 2004; Aiken et al., 2011). Intracellular GFP production in GFP transformed bacterial cells has also been shown to be a usefull indicator of cellular growth and growth inhibition by antimicrobials (Lehtinen et al., 2006; Deng et al., 2009; Hoogenkamp et al., 2015).

Previously, an in vitro assay based on the dependence of the fluosecence intensity of green fluorescent protein (eGFP) on intracellular $\mathrm{pH}$ (Kneen et al, 1998) has been used as a real time indicator of cellular viability in the biodeteriogenic fungus Aeureobasidium pullulans (Webb et al., 2001; Sabev et al. 2004). In this assay, constitutively expressed cytosolic eGFP was brightly fluorescent in viable cells due to the energy dependent maintanence of an intracellular cytosolic $\mathrm{pH}$ of ca. 7.58.0. However, in an acidic buffer or medium, cell death leads to the subsequent loss of intracellular $\mathrm{pH}$ regulaton, the acidification of the cytoplasm and consequent $\mathrm{pH}$ dependent reduction in eGFP fluorescence which can be quantified in real time and correlates with cell viability. 


\section{Materials and Methods}

\subsection{Antimicrobials and source}

With the exception of 4,5-dichloro-2-octyl-isothiazol-3-one (DCOIT) (Sanitized,

Switzerland) which was in powder form, all antimicrobials were supplied as liquids as follows: sodium pyrithione (40\%), Arch, UK; 1,2-benzisothiazol-3-one (BIT, 20\%), Thor, UK; 2-Octyl-isothiazol-3-one (OIT, 100\%), Sanitized, Switzerland; n-butyl-1,2benzisothiazol-3-one (BBIT, 100\%) Sanitized, Switzerland. Antimicrobials were dissolved in $10 \%(\mathrm{v} / \mathrm{v})$ ethanol in PBS $(\mathrm{pH} 6.0)$ or $\mathrm{LB}(\mathrm{pH} 6.0)$ to give stock solutions of $4 \%$ and $8 \%$ and used to challenge stationary or log phase cells repectively.

\subsection{Strains and culture maintenance}

Escherichia coli (BL21-DE3), which constitutively expresses cytosolic eGFP under the t7 promotor (Chew et al, 20112), was revived from glycerol stock cultures stored at $-80^{\circ} \mathrm{C}$ on LB agar (Sigma-Aldrich, UK) at $30^{\circ} \mathrm{C}$ for 2 days.

\subsection{Cultures, growth and viability determination}

E. coli (BL21-DE3) was cultured in $250 \mathrm{ml}$ conical flasks containing $50 \mathrm{ml}$ LB (adjusted to $\mathrm{pH} 6.0$ before inoculation) and incubated at $25^{\circ} \mathrm{C}$ on a rotary shaker at $200 \mathrm{rpm}$. Cultures were incubated for $18 \mathrm{~h}$ (stationary phase as determined by no additional increase in $\mathrm{OD}_{520}$ over 4 consecutive hours). For stationary phase tests, Page 5 
cells were harvested by centrifugation at $3000 \mathrm{Xg}$ for $10 \mathrm{~min}$, the supernatant discarded and the cells washed three times by resuspending in $50 \mathrm{mM}$ phosphate buffered saline (PBS, adjusted to $\mathrm{pH} 6.0$ ) and centrifuging at $3000 \mathrm{Xg}$ for $10 \mathrm{~min}$. After the final wash, the resulting pellets were re-suspended in $50 \mathrm{ml}$ PBS $(\mathrm{pH} 6.0)$ and incubated at $25^{\circ} \mathrm{C}$ for at least $6 \mathrm{~h}$ prior to use. For log phase tests, $250 \mu \mathrm{l}$ of the $18 \mathrm{~h}$ overnight culture was used to inoculate $50 \mathrm{ml}$ of LB broth (adjusted to $\mathrm{pH}$ 6.0) and used immediately.

\subsection{Correlation between culture absorbance, fluorescence and cell viability}

In order to determine if eGFP fluorescence intensity could be used as an indicator of cell viability for E. coli (BL21-DE3), $300 \mu$ of LB broth (adjusted to $\mathrm{pH}$ 6.0) inoculated with E. coli (BL21-DE3) was aliquoted into wells of a flat bottomed 96 well plate (Corning, UK) and incubated at $25^{\circ} \mathrm{C}$ in a microplate reader (Synergy HTMultiMode Microplate Reader, Biotek, UK) and fluorescence (excitation 488 nm, emission $520 \mathrm{~nm})$ and absorbance $\left(\mathrm{OD}_{520}\right)$ measured at 20 min intervals for up to $24 \mathrm{~h}$ from 8 wells with $15 \mathrm{sec}$ shaking immediately prior to the reading. Periodically, $5 \mu \mathrm{l}$ of cell suspension was removed from triplicate wells, serially diluted in PBS, plated in triplicate onto LB agar plates and incubated at $25^{\circ} \mathrm{C}$ for $48 \mathrm{~h}$ after which $\mathrm{CFU}$ per $\mathrm{ml}$ of the original culture was determined.

\subsection{Antimicrobial efficacy testing}

\subsubsection{Stationary phase antimicrobial efficacy determination}

For stationary phase tests, $150 \mu$ aliquots of the cells suspended in PBS $(\mathrm{pH}$ 6.0) and shaken for $6 \mathrm{~h}$ at $25^{\circ} \mathrm{C}$, were aliquoted into wells of a flat bottomed 96 well plate (Corning, UK) and $150 \mu \mathrm{l}$ of PBS containing $8 \%$ or $4 \%$ antimicrobial agent added to give final concentrations of $4 \%$ and $2 \%$ respectively and a final ethanol 
concentration of $2.5 \%(\mathrm{v} / \mathrm{v})$. To determine background fluorescence due to the antimicrobial agents, $150 \mu \mathrm{l}$ of PBS replaced the stationary phase cells. Wells containing $150 \mu \mathrm{l}$ of the cell suspension and $150 \mu \mathrm{l}$ of PBS were used as antimicrobial free controls and wells containing $300 \mu$ of PBS were used as negative PBS controls. Plates were incubated in a microplate reader (Synergy HTMulti-Mode Microplate Reader, Biotek, UK) at $25^{\circ} \mathrm{C}$. Fluorescence (excitation $488 \mathrm{~nm}$, emission $520 \mathrm{~nm}$ ) was measured at hourly intervals up to $24 \mathrm{~h}$ with $15 \mathrm{~s}$ shaking immediately prior to each measurement. To calculate the impact of the antimicrobials, the background fluorescence from antimicrobial-containing wells in the absence of cells was subtracted from the wells containing the antimicrobial agent and cells. Data was plotted as the mean fluorescence of triplicate wells following background subtraction.

\subsubsection{Log phase antimicrobial efficacy determination}

For log phase tests, $150 \mu \mathrm{l}$ aliquots of stationary phase cells suspended in 50 $\mathrm{ml}$ of LB broth $(\mathrm{pH}$ 6.0) were aliquoted into wells of a flat bottomed 96 well plate (Corning, UK) and incubated for $15 \mathrm{~h}$ in a microplate reader (Synergy HTMulti-Mode Microplate Reader, Biotek, UK) at $25^{\circ} \mathrm{C}$ and fluorescence (excitation $488 \mathrm{~nm}$, emission $520 \mathrm{~nm}$ ) measured at hourly intervals with $15 \mathrm{~s}$ shaking immediately prior to each measurement. After $15 \mathrm{~h}$, the 96 well plate was removed and $150 \mu \mathrm{l}$ of LB broth (pH 6.0) containing $8 \%$ or $4 \%$ antimicrobial agent added to give final concentrations of $4 \%$ and $2 \%$ respectively and a final ethanol concentration of $2.5 \%(\mathrm{v} / \mathrm{v})$ and incubated for a further $9 \mathrm{~h}$. To determine background fluorescence due to the biocides, $150 \mu \mathrm{l}$ of PD broth ( $\mathrm{pH}$ 6.0) replaced the cell suspension. Antimicrobial free controls in which there was no antimicrobial challenge were prepared by adding 150 $\mu \mathrm{l}$ of LB broth $(\mathrm{pH}$ 6.0) lacking antimicrobial agent to the wells and wells containing $300 \mu \mathrm{l}$ of media (no cells) were used as negative controls. To calculate the impact of 
172 the biocides, the background fluorescence from wells containing LB medium in the 173 absence of cells into which antimicrobial agent was added was subtracted from the wells containing biocide and cells. Data was plotted as the mean fluorescence of triplicate wells following background subtraction.

\section{Results and discussion}

Conventional antimicrobial efficacy testing requires time consuming viable colony counts or indirect measures of growth and growth inhibition. Here we used a constitutively expressed cyctosolic eGFP in E.coli (BL21-DE3) (Chew et al., 2012) that can readily distinguish between bacteriocidal and bacteriostatic effects by measuring changes in eGFP fluorescence in real-time.

\subsection{Correlation between eGFP fluorescence and cell viability in E. coli (BL21-} DE3).

E.coli (BL21-DE3) was grown in LB broth in a 96 well microtitre plate format and GFP fluoresence, absorbance and viable CFU determined periodically. The correlation between fluoresence intensity and viable CFU is shown in Figure 1. Fluoresence was shown to be significantly $(P<0.05)$ correlated with viable CFU up to ca. $5 \times 10^{8} \mathrm{CFU} \mathrm{ml^{-1 }}$ with an $\mathrm{R}^{2}$ of 0.9955 indicating fluoresence is a reliable indicator of cell viability. Recently, Alvalos Vizcarra et al (2013) also demonstrated a strong positive correlation between intracellular eGFP fluorescence and cell viability in $E$. coli (BL21-DE3) expressing eGFP under the control of the tac promoter, although in this study, eGFP was used to measure the percentage fluorescing cells microscopically rather than total fluorescence emission on a plate reader.

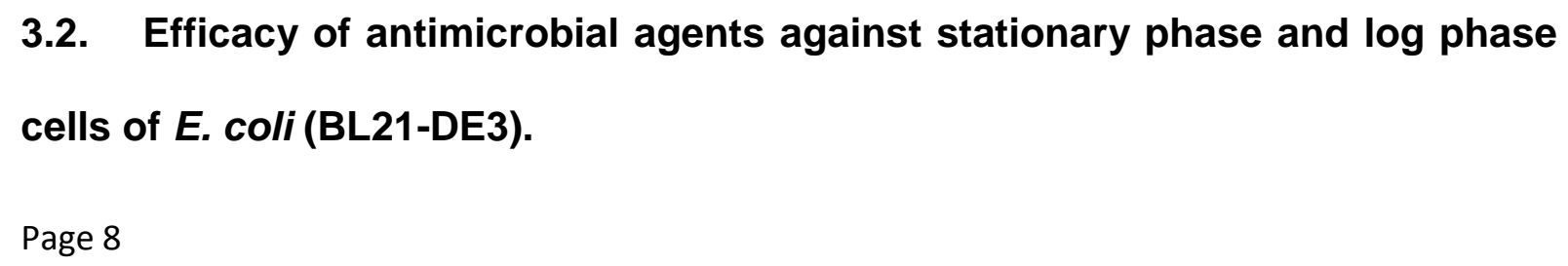


Numerous studies have indicated that the sensitivity of microbes to antimicrobial agents can be influenced by the metabolic state of the organisms and that non-growing cells are often more resistant compared to growing cells (Prax and Bertram, 2014). In order to study if antimicrobial efficacy was influenced by the metabolic state of E. coli (BL21-DE3), each biocide was used to challenge cells from both the stationary phase (non-growing) and log phase (growing).

\subsubsection{Efficacy of antimicrobial agents against staionary phase cells}

To study the effect of the antimicrobials on stationary phase cells, cells were grown for $18 \mathrm{~h}$ (stationary phase), washed and respended in PBS (pH 6) and shaken for $6 \mathrm{~h}$ before challenging with the antimicrobial agent and fluoresence monitored over $24 \mathrm{~h}$ (Fig 2A, C, E, G and I).

BBIT at both $2 \%$ and $4 \%$ was highly effective at reducing fluorescence (Fig 2A). After only $4 \mathrm{~h}$, both concentrations of BBIT showed a ca. $50 \%$ reduction in fluorescence when compared to the antimicrobial free control. For $2 \%$ BBIT, fluorescence remained approximately constant after $4 \mathrm{~h}$ whereas at $4 \%$ BBIT, fluorescence decreased further up to $24 \mathrm{~h}$ indicating a further loss in viability. Similarly, BIT also reduced fluorescence in E. coli (BL21-DE3) at both $2 \%$ and $4 \%$ but in this case there was a gradual decrease over $24 \mathrm{~h}$ by ca $30 \%$ (Fig $2 \mathrm{C}$ ).

Addition of $2 \%$ sodium pyrithione to E. coli (BL21-DE3) caused a ca. $50 \%$ reduction in fluorescence within the first hour after addition and then remained approximately constant up to $24 \mathrm{~h}$ whereas $4 \%$ sodium pyrithione rapidly reduced fluorescence to amost zero within the first hour (Fig 2E).

OIT caused a rapid reduction in fluorescence of ca. 35\% against $E$. coli (BL21DE3) within $1 \mathrm{~h}$ (Fig 2G) with little further affect thereafter at both $2 \%$ and $4 \%$ and 
DE3) with only $4 \%$ causing a reduction to ca. $75 \%$ after $24 \mathrm{~h}$ (Fig $2 \mathrm{~J}$ ). phase) cells, E. coli (BL21-DE3) was cultured in LB broth for $15 \mathrm{~h}$ in a microtitre plate before challenging with the antimicrobial agent at $2 \%$ or $4 \%$ and the effect on eGFP fluorescence determined over the subsequent $9 \mathrm{~h}$. caused a gradual reduction in fluorescence to ca. $40 \%$ respectively $9 \mathrm{~h}$ after antimicrobial addition (Fig 2B). When BIT was added to log phase cells of E. coli (BL21-DE3), cells reacted rapidly with a reduction in fluorescence to ca. $6 \%$ within 1 $\mathrm{h}$ of addition at both concentrations compared to the antimicrobial free control and remained low thereafter (Fig 2D). log phase cells to ca. $20 \%$ and ca. $5 \%$ within $1 \mathrm{~h}$ when challenged with concentrations of $2 \%$ and $4 \%$ respectively and then remained approximately constant thereafter (Fig 2F).

OIT displayed little efficacy against log phase cells of E. coli (BL21-DE3) at a concentration of $2 \%$ while at $4 \%$ fluorescence fell slowly to ca. $75 \%$ following antimicrobial addition (Fig 2H). DCOIT showed a similar effect against E. coli (BL21-

In order to study the efficacy of antimicrobial agents against growing (log

2\% BBIT had little effect on E. coli (BL21-DE3) log phase cells while $4 \%$

Sodium pyrithione caused a reduction in fluorescence in E. coli (BL21-DE3) 
stationary phase cells after $24 \mathrm{~h}$ and $1 \mathrm{~h}$ or $9 \mathrm{~h}$ after antimicrobial addition to growing log phase cells compared to the antimicrobial-free control is shown in Table 1.

\subsection{Comparison of antimicrobial agent efficacy and the effect of growth} phase

The antimicrobial agents used in this study have broad industrial applications including preservation of paints, adhesives and plastics as well for controlling microbial growth in cosmetics and industrial coolants such as metal working fluids and are used in this study at concentrations typically used in these applications (Denyer, 2005; Paulus, 2005; Rossmoore, 2005).

Comparing the effects of the antimicrobial agents, distinct differences could be seen both in terms of relative efficacy and in the rate of loss of viability. While some antimicrobials affected cells over the course of several hours and were relatively slow acting, for example BIT and BBIT on stationary phase E. coli (BL21DE3) cells (Fig 2A and 2C, Table 1), others had a rapid effect with their maximal effect within $1 \mathrm{~h}$ of exposure, for example $4 \%$ sodium pyrithione on stationary phase cells (Fig 2E, Table 1). Sodium and zinc pyrithiones are thought to affect microbial cell membranes of both bacteria and fungi (Hyde and Nelson, 1984; Khattar et al, 1988) and pyrithiones have been shown to effect substrate uptake, ATP synthesis and cause membrane depolarization leading to cell death (Dinning et al, 1998a,b; Khattar et al, 1988; Khattar and Salt, 1993; Ermolayeva and Sanders, 1995; Yasokawa et al., 2010) and would therefore be predicted to collapse the proton gradient leading to rapid cytoplasmic acidification and loss of eGFP fluorescence and viability. Log phase cells were more sensitive than stationary phase cells to some biocides (e.g. BIT, Table 1), while others appeared to effect stationary phase cells 
$\mathrm{F}$

\section{Page 12

DCOIT, OIT, BIT and BBIT are members of the Isothiazolone antimicrobials which are thought to have multiple modes of action but all appear to effect thiol rings within proteins leading to ring opening and deactivation thereby inhibiting key metabolic processes including energy generation through the Krebbs cycle as well as causing free radical accumulation (Williams 2007) and may explain the generally slower effect seen in this study. Interestingly, while BIT and BBIT, which differ only in an additional butyl group, were both active against stationary phase cells of $E$. coli (BL21-DE3) (Fig 2A and 2B), both 2\% and 4\% BIT reduced fluorescence to almost zero against log phase cells of E. coli (BL21-DE3) (Fig 2D) whereas BBIT was only active at $4 \%$ and showed less efficacy compared to BIT (Fig 2D) although both antimicrobial agents have been reported to have bactericidal activity (Nichols, 2005, Table 1). Similarly DCOIT and OIT, which differ only in DCOIT containing two chlorinated groups, were both active against E. coli (BL21-DE3) stationary phase cells (Fig 2G and 2I) but less effective against E.coli log phase cells (Fig $2 \mathrm{H}$ and 2J). Both antimicrobial agents have also been reported to have a broad antimicrobial activity (Paulus, 2005).

For several of the antimicrobials, an initial decrease in fluorescence against log phase cells was followed by growth (for example, DCOIT against log phase cells; Fig 2J, Table 1) suggesting the concentrations used temporarily inhibited growth but 


\section{Page 13}

Overall, this study has demonstrated the value of using eGFP as an in situ viability indicator in assessing the efficacy of industrial antimicrobial agents against $E$. coli (BL21-DE3) compared to conventional culture based counting and broth MIC determinations and has revealed that the impact of these antimicrobials on cell viability is a complex one, dependent on both the metabolic state of the cells as well as the agent itself. This technique enables both the rate and extent of the impact of antimicrobial agents on cell viability to be measured in real-time and as well as examining differential effects on growing and non-growing cells and could be adapted to study the kinetics of cell death in response to other antimicrobial agents including antibiotics.

\section{Competing interests}

The authors declare no competing interests. proportion of stationary phase cells while the remainder were still viable (for example BBIT and OIT against E. coli (BL21-DE3), Fig 2A and 2G respectively). This is not unexpected since antimicrobial agents show differing efficacies due to phenotypic variability within the same population (Turnidge and Paterson, 2007; Jorgensen and Ferraro, 2009).

\section{Conclusion}




\section{References}

Aiken, Z.A., Wilson, M., Pratten, J., 2011. Evaluation of ATP bioluminescence assays for potential use in a hospital setting. Infect. Cont. Hosp. Epidemiol. 32, 507-509.

Alloush, H.M., Salisbury, V., Lewis, R., MacGowan, A.P., 2003. Pharmacodynamics of linezolid in a clinical isolate of Streptococcus pneumoniae genetically modified to express lux genes. J. Antimicrob. Agents Chemother. 52, 511-513.

Allsopp, D., 2011. Worldwide wastage, the economics of biodeterioration. Microbiol. Today 38, 150-153.

Anderl, J.N., Zhaller, J., Roe, S., Stewart, P.S., 2003. Role of nutrient limitation and stationary-phase existence in Klebsiella pneumoniae biofilm resistance to ampicillin and ciprofloxacin. Antimicrob. Agents Chemother. 47, 1251-1256.

Avalos Vizcarra, I., Emge, P., Miermeister, P., Chabria, M., Konradi, R., Vogel, V., Moller, J., 2013. Fluorescence-based in situ assay to probe the viability and growth kinetics of surface-adhering and suspended recombinant bacteria. Biointerphases 8, 22.

Bloomfield, S.F., 1991. Methods for assessing antimicrobial activity. In, Mechanisms of Action of Chemical Biocides, Their study and exploitation. Eds SP. Denyer and WB. Hugo. Blackwell, Oxford, UK.

Boulos, L., Prevost, M., Barbeau, B., Coallier, J., Desjardins, R., 1999. LIVE/DEAD BacLight, application of a new rapid staining method for direct enumeration of viable and total bacteria in drinking water. J. Microbiol. Meth. 37, 77-86.

Chandler, C., Segel, I., 1978. Mechanisms of the antimicrobial action of pyrithione, effects on membrane transport, ATP levels and protein synthesis. Antimicrob. Agents Chemother. 14, 60-68.

Chapman, J.S., 2003. Biocide resistance mechanisms. Int. Biodeter. Biodegr. 51, 133-138.

Chew, F.N., Tan, W.S., Boo, H.C., Tey, B.T., 2012. Statistical optimization of green fluorescent protein production from Escherichia coli BL21DE3 Prep. Biochem. Biotech. 42, 535-550.

Cox, C., 1997. Fungicide factsheet, Chlorothalonil. J. Pest. Ref. 17, 14-20.

D'Arcy, N., 2001. Antimicrobials in plastics, a global review. Plast. Add. Comp. 3, 1215.

Davey, H.M., 2011. Life, death, and in-between, Meanings and methods in microbiology. Appl. Environ. Microbiol. 77, 5571-5576. 
Deng, D.M., Hoogenkamp, M.A., Ten Cate, J.M., Crielaard, W., 2009. Novel metabolic activity indicator in Streptococcus mutans biofilms. J. Microbiol. Meth. 77, 67-71.

Denyer, S.P., 1995. Mechanisms of action of biocides. Int. Biodeter. 26, 89-100.

Dhar, N., McKinney, J.D., 2007. Microbial phenotypic heterogeneity and antibiotic tolerance. Curr. Opin. Microbiol. 10, 30-38.

Dinning, A.J., Al-Adham, I.S.I., Eastwood, I.M., Austin, P., Collier, P.J., 1998a. Pyrithione biocides as inhibitors of bacterial ATP synthesis. J. Appl. Microbiol. 85, 141-146.

Dinning, A.J., Al-Adham, I.S.I., Austin, P., Charlon, M., Collier, P.J., 1998b. Pyrithione interactions with bacterial phospholipid head groups. J. Appl. Microbiol. 85, 132140.

Dylingowski, P.J., Hamel, R.G., 2005. Microbial degradation of plastics. In, Directory of Microbicides for the Protection of Materials. pp 325-342. Springer Netherlands.

Ermolayeva, E., Sanders, D., 1995. Mechanism of pyrithione-induced membrane depolarization in Neurospora crassa. Appl. Environ. Microbiol. 61,3385-3390.

Fux, C.A., Costerton, J.W, Stewart, P.S., Stoodley, P., 2005. Survival strategies of infectious biofilms. Trends Microbiol. 13, 34-40.

Hoogenkamp, M.A., Crielaard, W., Krom, B.P., 2015. Uses and limitations of green fluorescent protein as a viability marker in Enterococcus faecalis: An observational investigation. J. Microbiol. Meth. 115, 57-63.

Hyde, G.A., Nelson, J.D., 1984 Sodium and zinc omadine. In, Cosmetic and Drug Preservation, Principles and Practice. pp. 115-128. New York, Marcel Dekker

Jones, C., Robson, G.D., Greenhalgh, M., Eastwood, I., Handley, P.S., 2002. The development of a bioluminescence assay to compare the efficacy of biocides incorporated into plasticised PVC. Biofouling 18, 21-27.

Jorgensen, J.H., Ferraro, M.J., 2009. Antimicrobial susceptibility testing, A review of general principles and contemporary practices. Clin. Infect. Dis. 49, 1749-1755.

Karsa, D.R., Ashworth, D., 2002. Industrial Biocides, Selection and Application. Royal Society of Chemistry, UK.

Khattar, M.M., Salt, W.G., 1993. Aspects of the mode of action of pyrithione against Klebsiella pneumoniae. J. Chromatogr. 5, 175-177.

Khattar, M.M., Salt, W.G., Stretton, J.R., 1988. The influence of pyrithione on the growth of microorganisms. J. Appl. Bact. 64, 265-272.

Kneen, M., Farinas, J., Li, Y., Verkman, A.S., 1998. Green fluorescent protein as a non-invasive intracellular pH indicator. Biophys. J. 74, 1591-1599. 
Kun, E., Marossy, K., 2013. Evaluation methods of antimicrobial activity in plastics. Mater. Sci. Forum 729, 430-435.

La Fleur, M.D., Kumamoto, C.A., Lewis K., 2006. Candida albicans biofilms produce antifungal-tolerant persister cells. Antimicrob. Agents Chemother. 50, 3839-3846.

Lambert, P.A., 2008 Mechanism of action of biocides. In, Principles and Practice of Disinfection, Preservation and Sterilization. Eds, Adam P. Fraise, Peter A. Lambert and Jean-Yves Maillard. Blackwell Publishing, USA.

Lehtinen, J., Järvinen, S., Verta, M., Lilius, E-M., 2006. Real-time monitoring of antimicrobial activity with the multiparameter microplate assay. J. Microbiol. Meth. 66, 381-389.

Lewis, K., 2010. Persister cells. Ann. Rev. Microbiol. 64, 357-372.

Long, J.W., Siegel, M.R., 1975. Mechanism of action and fate of the fungicide chlorothalonil 2,4,5,6-tetrachloroisophthalonitrile in biological systems, 2. In vitro reactions. Chem-Bio. Interact. 10, 383-394.

Maillard, J-Y., 2002. Bacterial target sites for biocide action. J. Appl. Microbiol. 92, 16S-27S.

Markarian, J., 2006. Steady growth predicted for biocides. Addit. Comp. 8, 30-33.

Nichols, D., 2005. Biocides in Plastics RAPRA review reports Smithers RAPRA Technology.

Palková, Z., Wilkinson, D., Váchová, L., 2014. Aging and differentiation in yeast populations, elders with different properties and functions. FEMS Yeast Res. 14, 96-108.

Paulus, W., 2005. Directory of Microbiocides for the Protection of Materials, A Handbook, 2nd Edition. Springer, Netherlands.

Petty, R.D., Sutherland, L.A., Hunter, E.M., Cree, I.A., 1995. Comparison of MTT and ATP-based assays for the measurement of viable cell number. J. Biolum. Chemilum. 10, 29-34.

Poole, K., 2012. Bacterial stress responses as determinants of antimicrobial resistance. J. Antimicrob. Chemother. 67, 2069-2089.

Prax, M., Bertram, R., 2014. Metabolic aspects of bacterial persisters. Front Cell. Infect. Microbiol. 4,148.

Reeder, N.L., Xu, J., Youngquist, R.S., Schwartz, J.R., Rust, R.C., Saunders, C.W., 2011a. The antifungal mechanism of action of zinc pyrithione. Brit. J. Dermatol. $165,9-12$.

Reeder, N.L., Kaplan, J., Xu, J., Youngquist, R.S., Wallace, J., Hu, P., Juhlin, K.D., Schwartz, J.R., Grant, R.A., Fieno, A., Nemeth, S., Reichling, T., Tiesman, J.P., 
Mills, T., Steinke, M., Wang, S.L., Saunders, C.W., 2011. Zinc pyrithione inhibits yeast growth through copper influx and inactivation of iron-sulfur proteins. Antimicrob. Agents. Chemother. 55, 5753-5760.

Robinson, G.M., Tonks, K.M., Thorn, R.M.S and Reynolds, D.M., 2011. Application of bacterial bioluminescence to assess the efficacy of fast-acting biocides. Antimicrob. Agents Chemother. 55, 5214-5219.

Rossmoore, H.W., 1995. Handbook of Biocide and Preservative Use. Blackie Academic and Professional, Glasgow, UK.

Sabev, H.A., Handley, P.S., Robson, G.D., 2004. In situ quantification of biocide efficacy using GFP transformed Aureobasidium pullulans. J. Appl. Microbiol. 97, 1132-1139.

Sabev, H.A., Handley, P.S., Robson, G.D., 2006. Influence of starvation, surface attachment and biofilm growth on the biocide susceptibility of the biodeteriogenic yeast Aureobasidium pullulans. J. Appl. Microbiol. 101, 319-330.

Siegel, N.R., 1971. Reactions of the fungicide folpet [Ntrichloromethylthio phthalimide] with a thiol protein. Pestic. Biochem. Phys. 1, 225-233.

Swedish Chemicals Agency 2012a. Biocide Treated Articles - an Internet Survey. Swedish Chemicals Agency, Sweden.

Swedish Chemicals Agency 2012b. Efficacy Testing of Biocidal Products - Overview of Available Tests. Swedish Chemicals Agency, Sweden.

Thorn, R.M.S., Robinson, G.M., Reynolds, D.M., 2013. Comparative antimicrobial activities of aerosolized sodium hypochlorite, chlorine dioxide, and electrochemically activated solutions evaluated using a novel standardized assay. Antimicrob. Agents Chemother. 57, 2216-2225.

Tillman, R.W., Siegel, M.R., Long, J., 1973. Mechanism of action and fate of the fungicide chlorothalonil 2,4,5,6-tetrachloroisophthalonitrile in biological systems. Pestic. Biochem. Physiol. 3,160-167.

Turnidge, J., Paterson, D.L., 2007. Setting and revising antibacterial susceptibility breakpoints. Clin. Microbiol. Rev. 20, 391-408.

Vincent, P.G., Sisler, H.D., 1968. Mechanism of antifungal action of 2, 4, 5, 6 tetrachloroisophthalonitrile. Physiol. Plantarum 21, 1249-1264.

Webb, J.S., Barratt, S.R., Sabev, H., Nixon, M., Eastwood, I.M., Greenhalgh, M., Handley, P.S., Robson, G.D., 2001. Green fluorescent protein as a novel indicator of antimicrobial susceptibility in Aureobasidium pullulans. Appl. Environ. Microbiol. 67, 5614-5620.

Williams, T.M., 2007. The mechanism of action of Isothiazolone biocides. PowerPlant Chem. 7,14-22. 
457 Yasokawa, D., Murata, S., Iwahashi, Y., Kitagawa, E., Kishi, K., Okumura, Y., 1458 Iwahashi, H., 2010. DNA microarray analysis suggests that zinc pyrithione causes 459 iron starvation to the yeast Saccharomyces cerevisiae. J. Biosci. 460 Bioeng. 109, 479-486.

461 Zhang, T., Fang, H.H., 2004. Quantification of Saccharomyces cerevisiae viability 462 using BacLight. Biotechnol. Lett. 26, 989-992. 
467 The authors would like to thank MG consultants and Sanitized ag for financial 5468 support.

6 
Figure 1. Correlation between eGFP fluoresence and viable counts in a growing culture of E. coli (BL21-DE3). E.coli (BL21-DE3) was grown in a 96 well microtitre plate in LB medium at $25^{\circ} \mathrm{C}$ and fluoresence (excitation $488 \mathrm{~nm}$, emmission $540 \mathrm{~nm}$ ) and colony forming units (CFU) determined over $24 \mathrm{~h}$ after inoculation. CFU's were determined from serial dilutions on LB agar. Data represents the mean of at least 3 replicates \pm SEM. The line represents the best line of fit and $R^{2}$ the correlation coefficient.

Figure 2. Effect of the biocides BBIT, BIT, sodium pyrithione, OIT and DCOIT on the eGFP fluorescence of stationary phase and log phase cells of E.coli (BL21DE3). For stationary phase cells, an overnight culture of E.coli (BL21-DE3) was washed and resuspended in PBS $(\mathrm{pH} 6)$ with shaking for $6 \mathrm{~h}$ before dispensing into 96 well plates. Mean fluoresence of the cells was determined over $24 \mathrm{~h}$ following the addition of PBS (biocide free control, circles), $2 \%$ (squares) or $4 \%$ (triangles) BBIT (A), BIT (C), sodium pyrithione (E), OIT (G) or DCOIT (I). For log phase cells, overnight stationary phase cultures cells were diluted in LB broth and grown in 96 well plates for $15 \mathrm{~h}$ (log phase, circles) before the addition (indicated bh the vertical dotted line) of PBS (biocide free, circles), $2 \%$ (squares) or $4 \%$ (triangles) BBIT (B), BIT (D), sodium pyrithione (F), OIT (H) or DCOIT (J). Mean fluoresence of the cells was determined over $24 \mathrm{~h}$ (15 h prior to and $9 \mathrm{~h}$ after biocide additon). Data represents the means of three replicate wells \pm SEM. RFU $=$ Relative Fluoresence Units. 
Percentage Biocide Efficacy (\%E)*

\begin{tabular}{|c|c|c|c|c|c|}
\hline \multirow[t]{2}{*}{ Biocide } & \multirow[t]{2}{*}{ Concentration } & \multicolumn{2}{|c|}{ Stationary phase } & \multicolumn{2}{|c|}{ Log phase } \\
\hline & & Within $1 \mathrm{~h}$ & After $24 \mathrm{~h}$ & Within $1 \mathrm{~h}$ & After $9 \mathrm{~h}$ \\
\hline \multirow[t]{2}{*}{ BBIT } & $2 \%$ & $81.7 \pm 7.3$ & $65.5 \pm 5.9^{a}$ & $83.6 \pm 24.7$ & $85.4 \pm 22.6$ \\
\hline & $4 \%$ & $67.4 \pm 8.4^{\mathrm{a}}$ & $54.1 \pm 7.0^{\mathrm{a}}$ & $72.6 \pm 26.4^{\mathrm{a}}$ & $39.9 \pm 31.5^{\mathrm{a}}$ \\
\hline \multirow[t]{2}{*}{ BIT } & $2 \%$ & $87.6 \pm 4.7$ & $73.0 \pm 3.9^{a}$ & $7.1 \pm 8.1^{a}$ & $6.2 \pm 9.1^{\mathrm{a}}$ \\
\hline & $4 \%$ & $99.6 \pm 3.2$ & $65.2 \pm 2.6^{a}$ & $2.1 \pm 4.1^{\mathrm{a}}$ & $3.8 \pm 17.4^{\mathrm{a}}$ \\
\hline \multirow[t]{2}{*}{ Pyrithione } & $2 \%$ & $52.4 \pm 20.8^{\mathrm{a}}$ & $47.6 \pm 8.6^{a}$ & $19.0 \pm 21.3^{a}$ & $16.9 \pm 30.6^{\mathrm{a}}$ \\
\hline & $4 \%$ & $2.0 \pm 4.7^{\mathrm{a}}$ & $0^{\mathrm{a}}$ & $7.9 \pm 6.7^{\mathrm{a}}$ & $7.0 \pm 8.9^{\mathrm{a}}$ \\
\hline \multirow[t]{2}{*}{ OIT } & $2 \%$ & $33.9 \pm 7.9^{\mathrm{a}}$ & $41.4 \pm 8.3^{\mathrm{a}}$ & $92.0 \pm 9.9$ & $94.4 \pm 12.5$ \\
\hline & $4 \%$ & $36.0 \pm 5.4^{\mathrm{a}}$ & $29.9 \pm 7.3^{\mathrm{a}}$ & $96.2 \pm 25.1$ & $78.2 \pm 30.6$ \\
\hline \multirow[t]{2}{*}{ DCOIT } & $2 \%$ & $83.6 \pm 4.9$ & $30.0 \pm 2.0^{a}$ & $82.2 \pm 6.7$ & $94.1 \pm 14.1$ \\
\hline & $4 \%$ & $90.5 \pm 21.6$ & $29.4 \pm 20.9^{a}$ & $92.9 \pm 8.3$ & $78.6 \pm 24.2$ \\
\hline
\end{tabular}

$499{ }^{*}$ The percentage biocide efficacy (\%E) was calculated at 1 and $9 \mathrm{~h}$ after the addition 500 of biocide using the formula $\% E=F_{\text {biocide }} / F_{\text {control }} X$ 100) where $F_{\text {biocide }}$ is the 501 fluorescence of the biocide treated sample and $F_{\text {control }}$ the fluorescence of the 502 untreated sample. Means represent the average of three replicates \pm compounded $503 \%$ \%EM. ${ }^{a}$ Signifies a significant difference $\mathrm{P}<0.05$ ) compared to the biocide untreated 504 control (paired t-test). 
Figure 1

Figure 1

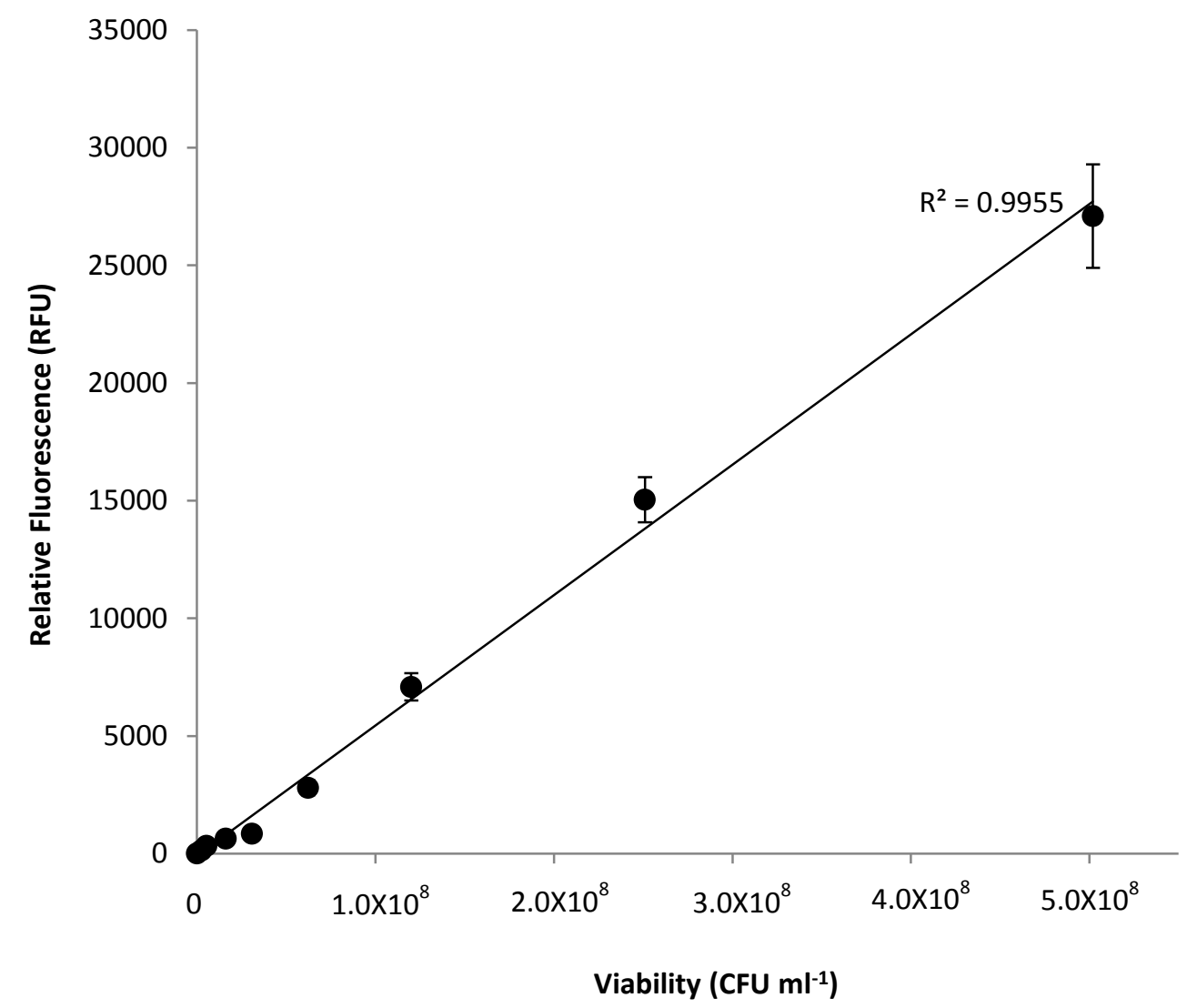


Figure 2
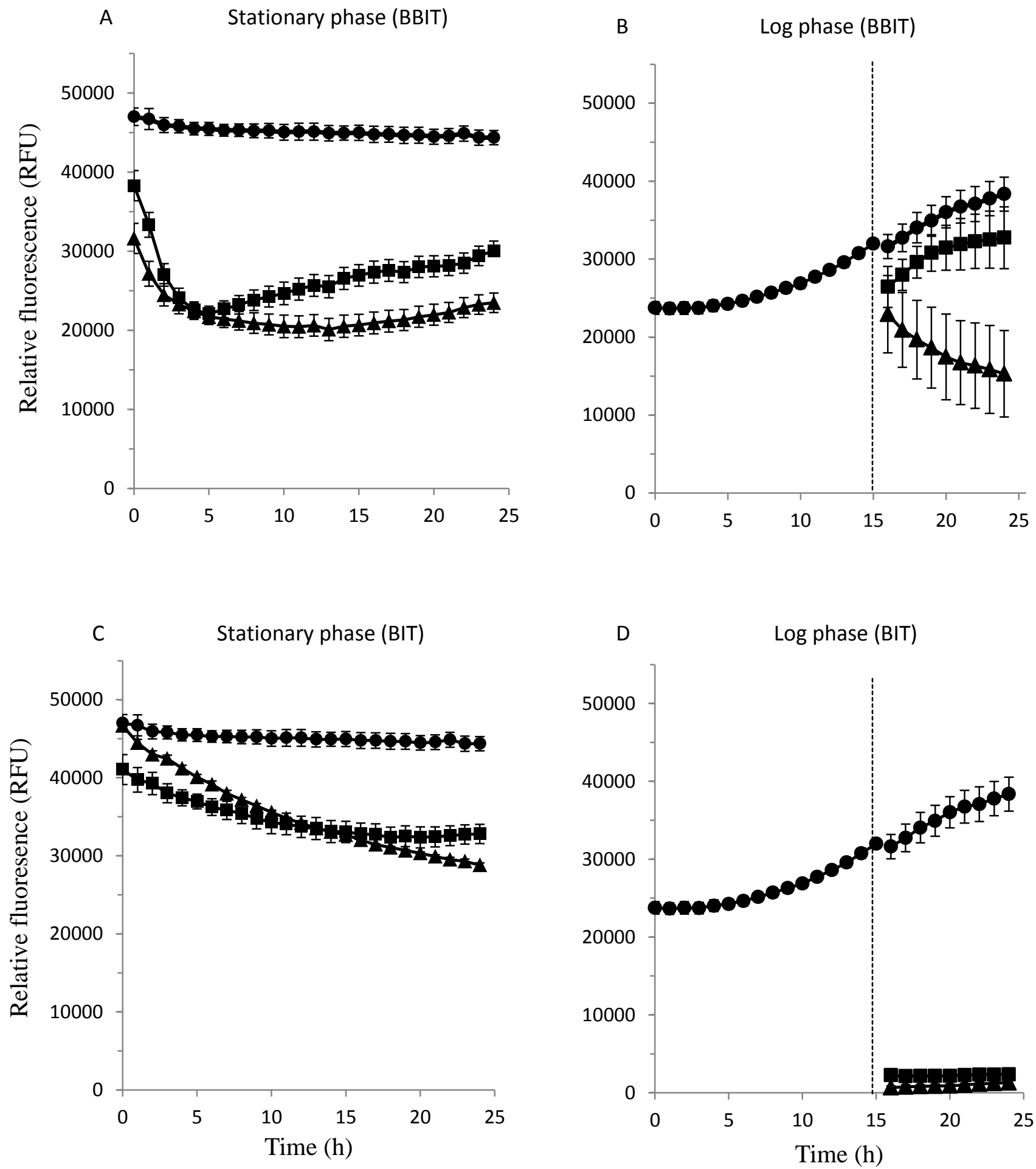
Figure 2 (continued)
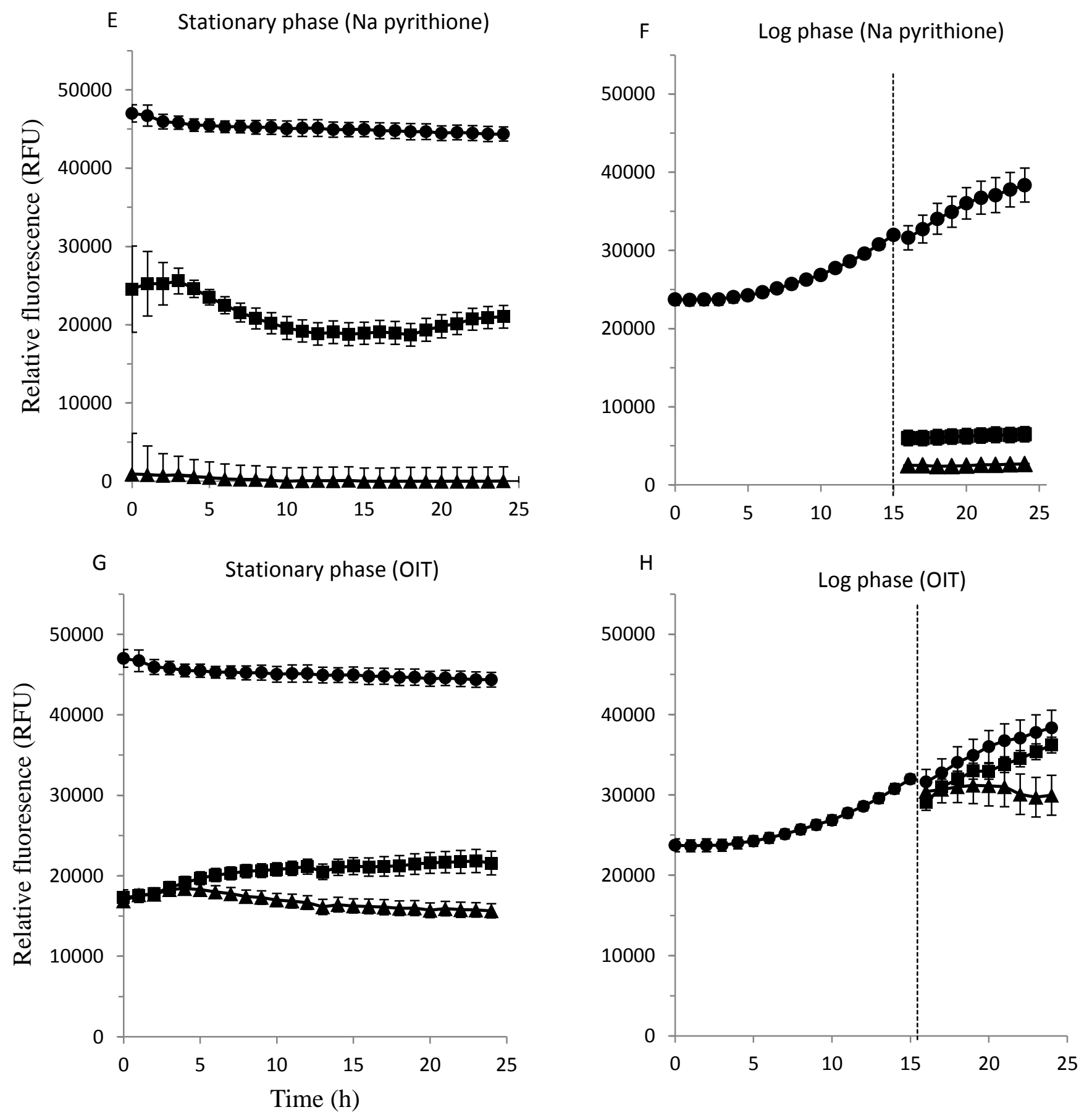
Figure 2 (continued)
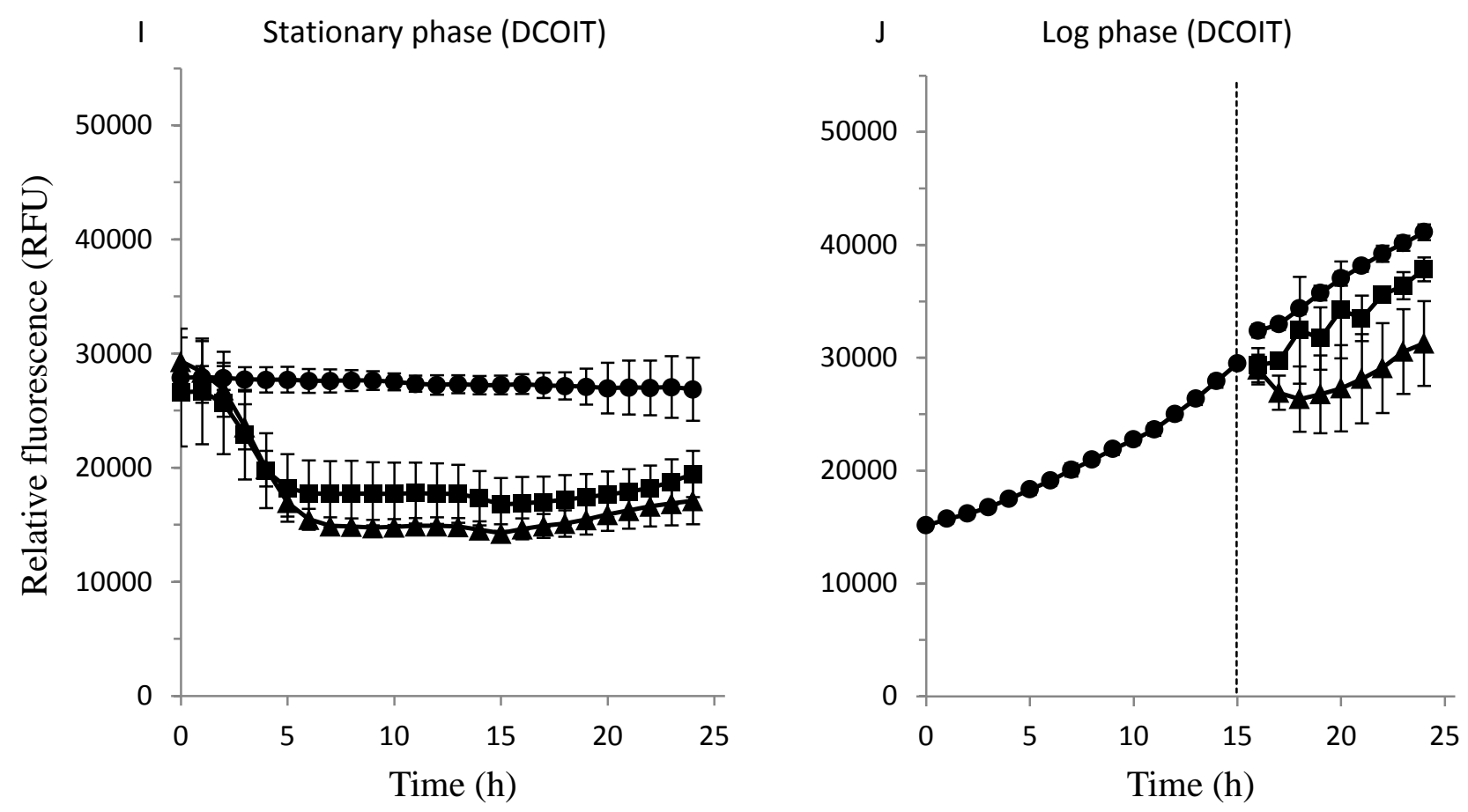